\title{
Vienna 1900 Revisited: Paradigms and Problems
}

\author{
Von \\ Allan Janik (Innsbruck)
}

It is an especially daunting task to do justice to the multifarious developments in the field of Austrian cultural history since the appearance of Professor Robert A. Kann's penetrating Study in Austrian Intellectual History. ${ }^{1}$ It will become clear in the course of this article that my praise of Kann is more than a pro forma courtesy. However, I should indicate at once that my concern is with his, alas neglected, contribution to the discussion of method in Austrian cultural studies.

My concern, then, is with models of explanation, rather than the strictly empirical side of research - although the two can never be fully separated. ${ }^{2}$ Indeed, it would scarcely be possible to survey the developments in the study of Austrian culture at the level of what I have termed for want of a better word "monographic" studies of fin de siècle Vienna ${ }^{3}$. By "monographic" studies I understand what Thomas Kuhn might term "normal" historical research such as documentation, which is carried on in the context of an established "paradigm", i.e., with established hermeneutic procedures for identifying questions and producing explana-

1 Robert A. Kann, A Study in Austrian Intellectual History: from Late Baroque to Romanticism (New York, Praeger, 1960). - This article is published with permission of the editors of the Austrian History Yearbook; it will appear in Nr. 28 (1997), 1-27. This article was originally presented as the Robert A. Kann-Memorial-Lecture at the center for Austrian Studies, Minneapolis, Minnesota.

2 Here we might paraphrase Kant and suggest that criticism of sources is blind in the absence of models of explanation which allow us to identify just what is worth researching in the first place; whereas models that are applied without mastery of sources are empty. The systematic study of sources, i.e., documentation yields a discourse for dealing with a particular set of "facts". However, to consider such research history is to confuse history with chronicle. It is in fact but the philological prolegomena to history. Models, on the other hand, offer perspectives on those facts which are such that they can be seen as relevant to other groups of facts, i.e., they are devices for unifying the various levels of discourse that have emerged from the study of sources. However, we often forget that we need models to do any research at ail, i.e., relatively simple "Vor-bilder" of what the results of our study of sources should be like. Nevertheless, the insight that perspectives provide will lack convincing power, if they are not developed from a close study of sources into a rich hermeneutic narrative, yielding a "thick" descriptions of significant facts.

3 Two problems crop up immediately as soon as one mentions "fin de siècle Vienna": what do we mean by "turn of the century" and what is the relation between Vienna and Austria. "Fin de siècle" can refer to any period from the 2-3 years before and after 1900 to the whole period from 1867 to 1938. My own preference is for the period roughly from 1890 to 1914 (or 1918). Similarly "Vienna" can refer to the city or "Austria" or eastern Austria. Normally these designations are not problematic. When they become so the crucial questions are "as opposed to what?" and "for what purpose?". 
tions. Rather, I am here concerned with what I have termed "interpretive" history, that sort of "revolutionary" research which aims at challenging established explanatory models and developing new ones by uniting hitherto disparate levels of discourse. Although, unlike Kuhn, I would not make the distinction between the two strictly dichotomous, especially as it applies to historical research. ${ }^{4}$

In what follows, if it should seem that I neglect my Austrian colleagues at the expense of my Anglo-Saxon ones, it is because Austrian work in the field, for all its frequent achievements, has tended to be "monographic" rather than "interpretative", to work within established paradigms, rather than developing new hermeneutic strategies.

The questions I want to pose are these: what has happened in the last thirty-five years? where are we now? and where should we go next?

The first and most obvious point to be made here is that Vienna - and Austria: right from the start we have as much trouble separating them as we do identifying them - have emerged in that period as objects of systematic study in their own right. Since 1960 cities in general have become interesting as fields of historical research. Vienna specifically has tended to exert a fascination upon the intellectual world which had so long neglected it. At the same time it became increasingly clear that Austrian culture could not simply be taken to be a series of footnotes to German history as it has often tended to be.

Among other significant developments in "monographic" studies — the sorts of things I shall not be talking about in what follows - that have taken place in the last thirty-five years we must include recognition of the role of both feminists and women generally played in Viennese life thanks to the painstaking researches of Harriet Anderson, Lisa Fischer and others. ${ }^{5}$ The study of Vienna's Jews has all but become a discipline in itself since the path-breaking work of Ivar Oxaal, Steven Beller and Marsha Rozenblit. ${ }^{6}$ The latter has called our attention to the role of the family in lending a collective identity to Jewish immigrants to Vienna that was not available to their Christian counterparts, who immigrated to the city as impoverished

4 On the notions of "paradigm", "normal science" and "revolutionary science" the locus classicus is Thomas S. Kuhn, The Structure of Scientific Revolutions (2nd ed.; Chicago, University of Chicago Press, 1970). For critical estimates of Kuhn see the essays in the volume Criticism and the Growth of Knowledge, eds. Imre Lakatos and Alan Musgrave (Cambridge, Cambrige University Press, 1970); cf. Martin Brody and Allan Janik, "Paradigms, Politics and Persuasion: Sociological Aspects of Musical Controversy", in my Style, Politics and the Future of Philosophy ("Boston Studies in Philosphy of Science", Vol. 114; Dordrecht, Kluwer, 1989, 225-31.) For a fuller account of my views on the problem of method in cultural history see my How Not to Interpret A Culture: Essays on the Problem of Method in the Geisteswissenschaften ("University of Bergen [Norway], Philosophy Department Stencil Series" nr. 73; Bergen, 1986).

5 Harriet Anderson, Utopian Feminism: Women's Movements in fin-de-siècle Vienna (New Haven, Yale University Press, 1992); Lisa Fischer, Lina Loos oder wenn die Muse sich selbst küßt (Vienna, Böhlau, 1994).

6 Ivar Oxaal, The Jews of Pre-1914 Vienna: Two Working Papers (Hull, 1981); Steven Beller, The Jews of Vienna 1867-1938: A Cultural History (Cambridge, Cambridge University Press, 1989); Marsha Rosenblit, The Jews of Vienna 1867-1914: Assimilation and Identity (Albany, SUNY Press, 1983). 
'singles' as it were. Monika Glettler has given us a rich picture of Vienna's Czech minority. ${ }^{7}$ Art historians like Peter Vergo ${ }^{8}$ have given us superb accounts of the main developments in painting, while studies of individual figures such as those of Alessandra Comini on Klimt and Schiele 9 have similarly enriched our knowledge as have a number of first class memoirs and biographies such as George Clare's Last Waltz in Vienna ${ }^{10}$ and Henry-Louis De La Grange's mammoth study of Gustav Mahler ${ }^{11}$ respectively. In general, the public imagination has been stimulated by captivating journalistic accounts of remarkable Viennese constellations of figures and events such as Frederic Morton's $\mathrm{A}$ Nervous Splendor. ${ }^{12}$ Finally, the opening of the east since 1989 has stimulated scholars there (with considerable support from Austrian sources) to reexamine their erstwhile ties to the Habsburg Monarchy with the hope of finding an important part of a lost identity. ${ }^{13}$ Indeed, the "monographic" literature has grown so large that it would be scarcely possibly to survey it adequately in the time available to me. In short, whereas it was frequently difficult to find material on many of the figures I wanted to write about twenty-five years ago - Klimt and Schiele as well as Loos and Musil come to mind at once - the wealth of material on them today is becoming as much a burden as it is a help to scholarship. This mountain of literature attests to the way that the story of Vienna has expanded in all sorts of directions.

Let me sketch the main developments in the last thirty-five with respect to explanatory hypotheses and the questions they imply briefly. During a long period the research of individual scholars was loosely guided by theses that were would-be paradigms such as Hermann Broch's notion of the Viennese "value vacuum", ${ }^{14}$ William Johnston's notion of "therapeutic nihilism" 15 , Ilsa Barea's view emphasizing the consequences of the Counter-Reformation in shaping the Viennese mentality and the city's image, ${ }^{16}$ and last but not least Robert Kann's cyclical model (to be discussed below) ${ }^{17}$. Finally, Carl Schorske's "failure of liberalism" thesis succeeded in providing a pattern around which a research field could crystallize ${ }^{18}$. He esta-

7 Monika Glettler, Die Wiener Tschechen um 1900 (Munich, Oldenbourg, 1972).

8 Peter Vergo, Art in Vienna 1898-1918 (London, Phaidon, 1975).

9 Alessandra Comini, Egon Schiele's Portraits (Berkeley, University of California Press, 1974); Gustav Klimt (New York, George Braziller, 1975).

10 George Clare, Last Waltz in Vienna (London, Ulverscroft, 1983).

11 Henry-Louis de la Grange, Mahler (3 Vols.; Paris, Fayard, 1979-1984).

12 Frederic Morton, A Nervous Splendor (New York, Viking, 1980).

13 For a typical example see the report of the research project Ambivalenz des Fin de Siècle: Wien Zagreb, eds. D. Barbaric and M. Benedikt (Vienna, Research report, Ministry of Science, Resarch, and Art, 1995).

14 Hermann Broch, Hofmannsthal and His Time, trans. M. Steinberg (Chicago, University of Chicago Press, 1984).

15 William Johnston, The Austrian Mind: An Intellectual and Social History 1848-1938 (Berkeley, University of California Press, 1972).

16 Ilsa Barea, Vienna: Legend and Reality (New York, Knopf, 1966).

17 See $\mathrm{n} 1$.

18 Carl E. Schorske, Fin de siècle Vienna: Politics and Culture (New York, Knopf, 1980). Since most of the French literature on Vienna descends from Schorske, it can be considered as part of the "Schorskean paradigm". See Michael Pollack, Vienne 1900: une identite blessé (Paris, Gallimard/Julliard, 1986), 10; cf. Jacques LeRider, Modernité viennoise et crises de lidentité (Paris, Presses Universitairs de France, 1989). The recent symposium on women at the turn of the 
blished a model which became the basis for the work of other scholars such as William McGrath and Michael Steinberg to mention but two of the best-known "Schorskeans". ${ }^{19}$

However, the publication of John Boyer's Political Radicalism in Late Imperial Vienna in 1981, when Schorske's book was still hot off the press, provided a covert challenge to the "failure of liberalism" hypothesis by altering our picture of Karl Lueger dramatically; ${ }^{20}$ whereas the first overt challenge to the adequacy of the "failure of liberalism" paradigm came from Steven Beller in his Vienna and the Jews of $1989 .{ }^{21}$ Beller argued convincingly that the mainstream of Vienna's so-called "assimilated" Jewry

1) was in fact the 'soul' of Vienna's liberal intelligentsia and

2) it neither deserted liberalism nor morality, even if it did not attain political power.

Alleging that Schorske neglected the enlightened-Jewish character of Viennese culture and the powerful stream of opposition to Viennese aestheticism and "the politics of fantasy" that it encouraged, i.e., what I have called "critical modernism", Beller claimed to offer a more satis factory paradigm for grasping the most important achievements of the Viennese fin de siècle in terms of precisely that attachment to moral values whose demise Schorske laments. Here we seem to have a clash of paradigms in the classical sense. I believe that much future research on the interpretive level will have to preoccupy itself with the relative merits of these two positions as well as the question of whether they are reconcilable.

What is it to have a paradigm in the first place? Despite considerable confusion in Kuhn's classical study of the development of scientific ideas, to have a paradigm seems to mean at least three things. ${ }^{22}$ First, it means that we are in possession of an hypothesis which allows or, better, requires - us to see things together that we previously only could perceive disparately. Secondly, a paradigm is itself an example to be imitated and further elucidated. Finally, a paradigm incorporates a bold conjecture which provokes criticism and thereby creates a common "field" of research by challenging its readers to enter into a systematic discussion. Briefly, our third point refers to nothing more than the fact that research within a paradigm is the activity of a community of scholars rather than isolated individuals. Where there were previously solitary scholars such as, say, Arthur May, who produced a highly informative, frequently insightful, overview in Vienna in the Age of Franz Joseph, ${ }^{23}$ it is first with "the failure of liberalism" that we have a matrix adequate to the interdisciplinary task of systemati-

century "Such-Bewegungen" indicates that much of current feminist thinking about Vienna 1900 proceeds from LeRider.

19 William McGrath, Dionysian Art and Populist Politics in Austria (New Haven, Yale University Press, 1974); Michael Steinberg, The Meaning of the Salzburg Festival: Austria as Theater and Ideology 1890-1938 (Ithaca, Cornell University Press, 1990).

20 John W. Boyer, Political Radicalism in Late Imperial Vienna: Origins of the Christian Social Movement 1848-1897 (Chicago, University of Chicago Press, 1981). The second volume of Boyer's study, Culture and Political Crisis: Christian Socialism in Power 1897-1918 (Chicago, University of Chigago Press, 1994) was not available to me at the time of writing this essay.

21 See n. 6; cf. my "Neuerscheinungen über die Kultur der Jahrhundertwende", Mitteilungen aus dem Brenner Archiv, 9 (1990), 101-2.

22 For a full account of the conundrums surrounding the nature of a Kuhnian paradigm see Margaret Masterman's "The Nature of a Paradigm", Criticism and the Growth of Knowledge, (see n. 4).

23 Arthur May, Vienna in the Age of Franz Josef (Norman, University of Oklahoma Press, 1966). 
cally identifying problems for research comprehensive enough at once to stimulate further research at the "interpretive" level and to evoke criticism of the paradigmatic interpretation itself.

As the creator of a new discussion of Vienna 1900 that brilliantly unified turn-of-the-century political and artistic discourse, Schorske is the father of us all who work in the field of Viennese cultural studies. His poignant exposition of politics and culture turned Vienna 1900 from a local phenomenon into something crucial for the whole of western culture with its twofold allegation that modern mass politics and the rejection of the bond between art and society simultaneously had their origins there. However, like Plato, who found it necessary "to lay unfilial hands" upon the thesis of "father" Parmenides, ${ }^{24}$ our very commitment to the enterprise of determining the causes and reasons which brought about the extraordinary hothouse of culture that was Vienna at the turn of the century, which we have inherited from Schorske, would seem to impel us to criticize him roundly.

I have till now refrained from mentioning the contribution of Janik and Toulmin to the discussion of Vienna at the turn of the century because I believe it must be located in the context of the development of the sorts of systematic research programs for understanding culture and society Vienna 1900 that are here under discussion. Briefly, the problem with Wittgenstein's Vienna ${ }^{25}$ is that it fits into both paradigms.

History often has a way of being stunningly implausible: it is, for example, not always 'historical' if one means by that simple chronological narrative. So "the failure of liberalism" thesis, and the paradigm that developed around it, was known long before Schorske published his book in 1980 because he had been publishing parts of it as articles as early as 1961 . The result was that the broader reading public first encountered the thesis as part of Wittgenstein's Vienna in 1973. Thus Herbert Marcuse greeted Stephen Toulmin shortly after our book was published with the words: "So you have written Schorske's book for him!". ${ }^{26}$ The authors of that book took what I have subsequently termed the "critical modernism" of Karl Kraus and company to be the reaction of what might be called the second generation of post-liberal intellectuals Viennese to the first. ${ }^{27}$ As far as Janik and Toulmin were concerned, Schorske's three essays, "Politics and the Psyche", "Politics in a New Key", and "The Transformation of

24 toletéon epitíthesthai tô patrikô logô, Plato, Sophist, 242.

25 Allan Janik and Stephen Toulmin, Wittgenstein's Vienna (New York, Simon \& Schuster, 1973).

26 Personal communication from Stephen Toulmin. Neither Prof. Toulmin nor I take this story as more than an amusing anecdote. For an account of what Stephen Toulmin and I saw ourselves as doing in writing that book, see my "In Place of an Introduction: Writing Wittgenstein's Vienna", Essays on Wittgenstein and Weininger ("Studien zur österreichischen Philosophie" Vol. 9; Amsterdam, Rodopi, 1985), 5-25. I have myself never been happy with the title of our book. The words "ethics" or "ethics of silence" should have appeared but they made the title too unwieldy. It was only around 1988 that I realized that the book should have been called "Cordelia's Silence" alluding to the inappropriateness of demanding that a supreme moral value, i.e., love be put into words.

27 This has nothing to do with generations as they are conceived, say, in political or military history, for intellectuals can be the same age and represent different constellations of values whereby one reacts upon the other as did, say, Hugo von Hofmannsthal and Karl Kraus who were both born in 1874. 
the Garden", 28 told the first part of a story, whose second part they told. They saw themselves clearly as working within the "failure of liberalism" paradigm. It is important that despite the title "Wittgenstein's Vienna", which was a compromise from the start, they did not see their book as being about Vienna except secondarily. In the first instance it was a study of the social and intellectual origins of Wittgenstein's injunction to silence at the end of the Tractatus. The point is that Schorske's public had to be different from what he might originally have imagined as the result of the publication of Wittgenstein's Vienna seven years before his book because the terms of the discussion had been altered (at least as concerns the broader public).

All this would merely be an exercise in vanity on my part were it not for the fact that Schorske's work too has been subject to considerable misunderstanding, at least from his point of view, inasmuch as it has been read as a definitive, comprehensive study of the relation between politics and culture in Old Vienna as opposed to the case study in the origins of antihistorical thinking that he claims it is in his preface. ${ }^{29}$

The upshot is that neither of the two best-known books about Vienna at the turn of the century claim to be principally books about Vienna at the turn of the century. One is an account of the background to a very curious philosopher's efforts to "show", i.e. gesture at with words, something which cannot be said explicitly, and the other about the Viennese origins of the twentieth century retreat from history and the McCarthyite mentality.

Clearly enough each of these first-person views is absurd, even if it is true. In the end the intention implicit in the work itself is more important than the subjective intentions of the author as has been clearly demonstrated in the case of painters and painting (although they need not be mutually exclusive). ${ }^{30}$ Both Schorske and Janik and Toulmin have written books about Vienna, whatever they may say themselves.

But the paradoxes do not end there, for Wittgenstein's Vienna is an important source of arguments for the "critical modernist" thesis that would come to challenge the "failure of liberalism" paradigm. For this reason its author is more than a little interested the question of whether there is actually a "revolutionary" clash of paradigms here or merely a dramatic instance of "normal" criticism.

While there is certainly no need to belabor the details of the model that is at the heart of the Schorske paradigm to this audience, let me refresh your memories with respect to its main lines.

28 The first and third appeared originally in the American Historical Review, Vol. 68 (July, 1961), 930-46 and Vol. 72 (July, 1967), 1283-320 respectively; whereas the second was first printed in the Journal of Modern History, Vol. 39 (December, 1967), 343-86.

29 Schorske, op. cit, xii-xxii (see n. 18); cf. Michael Roth, "Performing History: Modernist Contextualism in Carl Schorske's Fin-de-Siècle Vienna", American Historical Review, Vol. 94 (June, 1994), 729-745.

30 On the important distinction between the intentions of the artist and the intentions immanent in the work of art see Tore Nordenstam, "Intention in Art", Wittgenstein. Aesthetics and Transcendental Philosophy, eds. Kjell S. Johannessen and Tore Nordenstam (Vienna, Hölder-Pichler-Tempsky, 1981), 127-35. 
The "failure of liberalism" thesis is first and foremost a thesis about the way in which the political frustrations of the Viennese upper middle class turned it from a patient, rational, "scientific-moral" attitude to life and society embodied in the historicist architecture of the Ringstrasse, to a decadent, narcissistic preoccupation with self-fulfillment. It explains, in short, how the pursuit of high culture became a surrogate for political engagement for the second generation of Viennese liberals as racist demagogues undermined the nascent liberal political order at the same time that Nietzsche's "Dionysian", ecstatic ideal of self-fulfillment poisoned the minds of a youth who could no longer see any sense in political engagement - the parallels to Allan Bloom's subsequent thesis in The Closing of the American Mind ${ }^{31}$ are striking indeed. In aesthetics this transition is marked by the rejection of the aesthetic ideal of naturalism, i.e., Zola's notion of a politically engaged, critical art working towards enlightenment in society in favor of an impressionist or symbolist fascination with the poetic elucidation of subjective states, i.e., what Hermann Bahr called a "Romanticism of nerves"32. On this view the work of Arthur Schnitzler is the nostalgic embodiment of the abandonment of "moral-scientific" culture for hedonism, whereas that of Hugo von Hofmannsthal epitomizes the growing fixation with the hedonist's self, and comes to incorporate a kind of hedonist's bad conscience, that posits a surrogate society to give itself the very 'social space' from which it has in actuality severed itself. Thus in Schnitzler's The Green Cockatoo a half-aestheticized relation to society expresses itself as self-alienation and a fatalistic defenselessness before the politically inevitable; whereas in Hofmannsthal it becomes the effort to move the populace to fellow-feeling utilizing all of the forceful emotional effects of the Wagnerian Gesamtkunstwerk. as the latter did in, say, The Woman Without a Shadow or The Tower. Ultimately Austria itself becomes conflated narcissistically with its theatrical self-image as incorporated in the Salzburg Festival. ${ }^{33}$

The lower middle class version of this "politics of fantasy" is a demagogic exploitation of theatrical gesture for narrow political ends, or better, making theatrical effectiveness, and the wishful thinking it entails, instead of rational decision based upon the greatest good for the greatest number with each counting as one, the basis of political life. Invented by the fanatical Pan-German racist, Georg von Schönerer, this "politics of fantasy" is perfected in the opportunist anti-Semitism that paved Karl Lueger's way to power as mayor of Vienna on the basis of a Romantic vision of a medieval corporate state, and, astonishing as it seems, in Herzl's Zionist utopia, which exploited Jewish Messianism in just the same way that Lueger's Christian-social movement exploited ideologically the archaic image of medieval Catholicism, or Schönerer's Pan-German movement a mythical Deutschtum. Freud fits into the picture as providing, if not a fantastic ideological vision of a utopia, radical skepticism about rational motivation and moral values by producing an account of motivation entirely rooted in egoism. Like Schönerer, Lueger and Herzl, Freud's personal frustrations with his father and the values of his father's generation provides the crucial clue about why he rejects liberal rationality. Gustav Klimt's withdrawal from being the public-spirited artist producing frescoes for the

\section{Allan Bloom, The Closing of the American Mind (London, Penguin, 1988).}

32 Hermann Bahr, "Die Überwindung des Naturalismus", reprinted in Die Wiener Moderne, ed. G. Wunberg (Stuttgart, Reclam, 1980), 202.

33 The last point is Michael Steinberg's extention of the Schorske thesis (see n. 18). 
"Apollonian" embellishment of public life in the Burgtheater into an ever-deepening glorification of unbridled, "Dionysian", sexuality in the monumental paintings for the university aula, exemplifies the tendency of the society as a whole to withdraw from the public into the private, from society into the self, and ultimately from rationality to irrationality. So widespread was this withdrawal that not even the work of such Viennese giants as Arnold Schoenberg and Adolf Loos could escape its temptations entirely. Thus we should not be shocked when we find Hitler at once admiring Schönerer and Lueger, as well as referring to Vienna as the most difficult, most thorough, school in his life ${ }^{34}$. Indeed, the "failure of liberalism" thesis would appear to be based to a great extent on Hitler's view of Vienna before the Great War.

The "failure of liberalism" model is, then, a thesis about the inability of liberal high culture to respond rationally to failure in the political arena, and its withdrawal, at worst, into complete hedonism; at best, into a nostalgic mystical concept of public life, that was completely incapable of facing the challenges, which rapidly modernizing Viennese society presented. Its three pillars are an analysis of the Viennese "politics of fantasy", account of the Viennese rejection of literary Naturalism and the conceptual apparatus of psychoanalysis, which supplies simultaneously the conceptual basis of the rejection of delayed gratification in politics and the substitution of an aesthetics of wish fulfillment for engagement in the arena of actual political conflict.

The result of such bold moves as associating the founder of modern Zionism with anti-Semitic demagogues, or of interweaving an analysis of the external disorder of the brawls in the Viennese parliament with the internal disorders in the psyches of Nietzschean decadents, as well as Schorske's graphic portrayal of the way that the cultural burden on the liberals' sons often evoked self-destructive tendencies to cultural patricide in them, is simply dazzling - so much so that on first glance we are easily tempted to accept uncritically the magnificent set of portraits that he presents.

The fact that many readers failed to pay attention to the claim that the real theme of Schorske's work was how we could find striking examples of the retreat from history that we find ubiquitous in Viennese society led them to pose a number of questions about the incompleteness of Schorske's work, which Schorske himself does not seem to consider relevant to his work, but which remain, nevertheless, crucial to the "failure of liberalism" paradigm. Above all, for anyone with the slightest tinge of historical materialism in their consciousness, the question, who were these liberals after all? jumped out of the book. Schorske himself offers us no answer. Apart from the names of two of the liberal mayors of Vienna liberalism was little more than the set of values that informed the writings of Stifter, and Saar but found their most perfect realization in the decoration of - and the debates surrounding - the buildings on the Ringstrasse. In the event John Boyer would tell us who they were.

Just at the point that Fin de siècle Vienna: Politics and Culture began to circulate a powerful challenge to its main thesis was issued so quietly in Boyer's work that scholars for the most part have failed to this day to notice the vast implications of his brilliant researches into Vien-

34 "Vienna was a hard school for me, but it taught me the most profound lessons of my life", Hitler cited in Alan Bullock, Hitler: A Study in Tyranny (New York, Bantam, 1961), 13. 
nese politics for the study of Viennese culture. ${ }^{35}$ In showing us exactly wherein Karl Lueger's political achievements lie Boyer also explained what political liberalism in Vienna was really all about, i.e. what liberals aspired to and why fundamental contradictions in their program determined that they had to fail. I refer to the anti-democratic stance of the Viennese liberals' efforts to maintain the franchise exclusively for those who paid 10 florins tax, i.e., at about $5 \%$ of the population, ${ }^{36}$ was wholly incompatible with their cultural 'mission' of uniting the Bürgertum, and thus could only be regarded as a provocation to the excluded "little men", who were after all the vast majority. In effect the liberals of the 70s betrayed the cause of the liberals of 1848 , namely the political unification of the middle classes. ${ }^{37}$ To put it glibly, the liberals were not very liberal and in their own illiberalism provoked an even more dangerous illiberalism that destroyed them politically.

Moreover, Boyer's analysis deftly demonstrates that Lueger, far from being a fanatic, was in fact Vienna's first professional politician, ${ }^{38}$ something best illustrated by his refusal to settle political debates in duels. In bringing disparate, indeed conflicting, economic groups such as artisans and their landlords into one party Lueger in fact realized the highest aspiration of Viennese liberals of an earlier generation. Boyer argues - actually less convincingly than he might have if he had given us some examples of comparative rhetorical tactics - that Lueger's type of political leadership actually had more in common with the Baroque notion of the ruler as "father" than the totalitarian "leader", i.e., that Lueger was paternalist rather than 'proto-fascist'.

In creating a successful political party out of conflicting interest groups Lueger was wholly sensitive, as the genuinely fanatical and self-destructive Schönerer was not, to the dual dimension of Viennese political life. From the Baroque onwards its public face had been profoundly theatrical. ${ }^{39}$ Think of how the emperor would wash the feet of twelve poor men and wait upon them in the imperial palace on Holy Thursday, ${ }^{40}$ or the ceremony of the burial of an emperor in which the grand master of the court would stand before the door of the Capuchin church in the first district asking three times for admittance, being refused first as Emperor and King, and then as "Apostolic King of Hungary, King of Bohemia, Dalmatia, Croatia, Slavonia, Galicia, Lodomeria, Illyria, Jerusalem [!], Archduke of Austria, Grand Prince of Transsylvania, Grand Duke of Tuscany and Krakow, Duke of Lorraine, Salzburg, Styria, Carinthia, and Carinolia", only to be admitted at the moment that the deceased emperor was identified as a man begging God's mercy. ${ }^{41}$ So Lueger knew that theatricality was necessary to success in public life. To that end he espoused anti-Semitic rhetoric as "spice" for the public's taste for enter-

35 Boyer's work is a good example of work that is conceived and presented as "normal" or "monographic" history in the sense used here but is in fact "revolutionary", i.e.,"interpretive". This is possible in history where, unlike natural sciences, the models which inform research are often largely unarticulated and are never formal.

36 Boyer, op. cit., 26 (see n. 20).

37 Ibid., 37.

38 Ibid., 411-21.

39 Loc. cit.

40 Arthur May, The Habsburg Monarchy 1867-1914 (New York, Norton, 1968), 147.

41 Johnston, op. cit., 58 (see n. 15). 
tainment (in direct imitation of the way that liberals used anti-clerical rhetoric ${ }^{42}$ ). But he well knew that this was only the public side of Viennese politics, in private there was in fact very little elbow room for maneuvering: compromise reigned supreme. In short, Boyer's Lueger has very little to do with the merely charismatic Lueger of the "failure of liberalism" thesis even if he presents as many problems as he illuminates ${ }^{43}$ - but Boyer's treatment of Lueger does draw our attention to aspects of Viennese tradition especially the Viennese tolerance for ambiguity with respect to the difference between the public and private meaning of words and events that are crucial for understanding Viennese culture. ${ }^{44}$ In a nutshell Boyer's research shows clearly that we cannot begin to understand the relationship of culture to politics till we raise the question of the nature of Viennese society and its values. Without a social history of Vienna the relation between politics and culture is a purely hypothetical one.

After Boyer's work the "failure of liberalism" thesis had begun to limp badly, for it was no longer possible to lump together the immensely successful, if vulgarly, even dangerously opportunistic, Lueger with the fanatic, ne'er-do-well Schönerer, whose main achievement was to get himself banned from Austrian public life. Subsequent work by Klaus Dethloff shows that the picture of Herzl presented in the "failure of liberalism" thesis was equally one-sided. To be sure Herzl did, like Lueger, have a marked flair for the dramatic with his deep debt to Wagner and the concept of the Gesamtkunstwerk, ${ }^{45}$ both of whose importance for Vienna 1900 is immeasurable. Consider, for example, his plan for a baptism en-masse for the Viennese Jews or a duel to the death with a leading anti-Semite. However the principle behind Herzl's thinking was eminently rational, namely legal recognition of the Jews as a "nation" the only move which, as we now know, could really have undercut the evil thrust of political anti-Semitism. Indeed, Dethloff argues convincingly that Herzl, an educated lawyer, in fact was entirely realistic in his efforts, first, to achieve recognition for the Jews as "Volk", secondly, to establish a state for that "Volk" on the basis of the principle, negotiorum gestio

42 Boyer, op. cit, 210 et passim (see n. 20).

43 It is important to emphasize that Boyer's picture of Lueger in no sense absolves Lueger from the responsibility for the spread of rabid anti-Semitism in Vienna, for, as Boyer emphasizes, Lueger certainly tolerated real fanatics in his entourage. However, Boyer's position does falsify Schorske's picture of Lueger as merely a charismatic figure whose political practices were somehow less realisitic than those of his predecessors. The question of responsibility thus turns out to be more complicated than a thesis like Schorske's would suggest. But then responsibility in these matters is a highly complex matter as Karl Jaspers insisted in his classic The Question of German Guilt, trans. E.B. Ashton (New York, Capricorn, 1947), 31-46.

44 Boyer, op. cit., 414 (see n. 20).

45 The concept of Gesamtkunstwerk is a murky one inasmuch as Richard Wagner developed a notion for the co-operation between artists under that rubric than in fact apply to his work. The term later came to be applied to his music dramas with respect to the way in which they captivate and overpower the audience with a view to moving the audience to see the world differently. In effect, the Wagnerian Gesamtkunstwerk aims at something akin to a religious conversion. See Peter Revers, "Erlösung dem Erlöser - Wer erlöst uns von dieser Erlösung": Zur Rezeption des Erlösungsgedankens bei Wagner und Nietzsche", Der Fall Wagner, ed. Thomas Steiert ("Thurnauer Schriften zum Musiktheater", no. 11; Laaber, Laaber Verlag, 1991), 137-46. For an example of the importance of this concept see James Shedel, Art and Society: the New Art Movement in Vienna 1897-1914 (Palo Alto, Society for the Promotion of Science and Scholarship, 1981), 29-30 et passim. 
drawn from Roman Law. ${ }^{46}$ That principle permits a person to act on behalf of another when the latter's property is endangered. As a precedent it could be appealed to in order to make a "Volk" out of Central European Jewry. Reading Dethloff carefully it is clear that Herzl was fully conscious of the dual aspects of Viennese politics, the theatrical and the pragmatic, to which Boyer has called our attention, and was prepared to act strategically, both histrionically in the theater of public politics, and with sober legal acumen behind the scenes. If this is true, the "politics of fantasy" involved in winning recognition for his people in a duel or through mass conversion in St. Stephen's Cathedral is but the Romantic political "husk" of a politics whose rational "kernel" is to be found in its attachment to legality - something very Jewish. However, that would imply, as does Boyer's revised portrait of Lueger, that the concepts and strategy that have given us the "failure of liberalism" hypothesis are hardly adequate to doing justice to the complexities of Viennese political culture.

These are just some of the problems that have led scholars to seek an alternative which would be able to accommodate the main points in the "failure of liberalism" but at the same time tell a more comprehensive story.

At this point I want to introduce Robert Kann into the picture. Kann's thesis, which to my knowledge has never really been explored, is that there is a cyclical pattern in Austrian intellectual life inasmuch as two alternating constellations of values dominate within Austrian society in succeeding generations. In short, there is not one "Austrian mind", but two, between which the country vacillates - roughly corresponding to the theatrical, and the pragmatic sides of political life. ${ }^{47}$ One of these mentalities is at once sentimentally nostalgic and highly moralistic in the spirit of counter-reformation Catholicism: eloquence and wit are its earmarks. The other is more dryly reformist and rationalistic seeking to introduce the "values of the Enlightenment" into a country to which they are basically foreign. ${ }^{48} \mathrm{Kann}$ made his thesis come to life by illustrating it vividly in the persons of the anti-Semitic Baroque court preacher Abraham a Santa Clara, who ultimately represents entertainment, and the culture of the picture, and the assimilated Jewish Professor of "Polizei- und Kameralwissenschaft", later president of the Academy of Fine Arts, Josef von Sonnenfels, the leading representative of the Enlightenment, who represents the critical culture of the word. These two were important to Kann as much for what they symbolize as for what they actually did —or failed to do: the one for his dazzlingly witty mixture of moralizing entertainment, the other for his Promethean, if

46 Such recognition was the only move which would have undermined political anti-Semitism, i.e., the concept of Jews as "parasites" in German culture. Klaus Dethloff, Theodor Herzl oder Der Moses des Fin de Siècle (Vienna, Böhlau, 1986), 36 et passim.

47 Kann, op. cit., xiii (see n. 1).

48 Here it is worth quoting Kann at length: "The genuine Liberal in German Austria does not occupy a firm middle ground between the party ideologies of political Catholicism, integral nationalism, and Socialism. He is at times - more often than not erroneously - to some extent associated with one of them, but generally attacked by all of them [...]. The liberal position is even more seriously jeopardized by its later failure to cope with social, national, and historical traditional problems. Above all, it has never had a social group support equal in strength to that of any of the other groups mentioned." ibid., 255. 
frustrated, effort to introduce the values and practices of secular "civil society" into Austria. 49 They were "type-forming characters" who were the key to understanding the dominant mentality in successive generations.

The speculative character of Kann's thesis doubtlessly accounts for its neglect by historians of Austrian culture. This mode of attacking the problem of understanding Austrian intellectual history would seem to be indebted in some loose sense to Giambattista Vico's view of history as a spiral process of corsi and recorsi..$^{50}$ It is hardly a secret that such cyclical views of history are neither particularly easy to grasp, nor to reconcile with empirical detail. Moreover, the idea of a "type-forming pattern" is not particularly easy to fathom: is he giving us criteria for the explanation of Austrian cultural development over generations, or heuristic hints about what to look for in the 'mentality' of succeeding generations? There is a big difference here. The former is hard to swallow; the latter is, however, highly suggestive with respect to the hermeneutic possibilities it offers, both with respect to the peculiarities of Austrian Catholicism and the situation of assimilated Jewish enlighteners, neither of whose importance can be exaggerated.

Be that as it may, Kann had very specific ideas about the fact that these alternating periods would illuminate one another. Thus he insists that we shall only understand developments in one generation by looking carefully into developments in the last generation but one. But is this not exactly what Boyer suggests that we must do if we want to see Lueger rightly? For readers of Kann Boyer's account of Lueger contains no surprises. So, even if we are suspicious of sweeping generalizations, we disregard Kann at our peril. Kann's model can usefully guide us by reminding us of the need to think of the long term when we are trying to get hold of the basic values of specific individuals in specific epochs.

That brings us to Ilsa Barea. In her superb Vienna: Legend and Reality she employs just such a long term perspective to explain how Vienna came to have a carefree image, "cheerful Vienna" that has precious little to do with life there. With an irony seldom surpassed in Austrian cultural historiography she relates how even figures who contributed significantly to that image were in fact victims of harsh Viennese realities. Mozart is perhaps the most dramatic case in point. Always happier in Prague, he lies buried ignominiously in a common grave, whose whereabouts will probably always remain unknown; while his music has become the very symbol of a city, that for the most part rejected him in life, only to celebrate him after his death by erecting a lovely memorial to him in a cemetery where he does not lie - and, finally, to have the national bon-bon, the Mozartkugel, named after him. This is not an atypical Viennese destiny.

Barea's explanation for this attitude takes us all the way back to the counter-reformation, which imposed Catholicism on a city that had gone overwhelmingly over to Protestantism almost as soon as Luther nailed his theses to the door of the Wittenberg cathedral. ${ }^{51}$ While it took a century to do so, the Catholic Habsburgs wiped out Protestantism by forcing emigra-

49 On civil society see the contributions of Edward Shils and Charles Taylor in Europa und die Civil Society, ed. K. Michalski (Stuttgart, Klett-Cotta, 1991), 13-51, 52-84.

50 On Vico see Isaiah Berlin, Vico and Herder (London, Chatto \& Windus, 1976), 64 et passim.

51 Barea, op. cit., 45ff (see n. 16). 
tion or re-conversion. The implications of Barea's position, which she does not herself elicit from her position as I do here, are as deep as they are wide for our understanding of Viennese culture. Thus the effects of this forced conformity go a long way to explaining the most prominent characteristics of the Viennese popular mentality in comparison with, say, the Berliner mentality circa 1900: obsequiousness, melancholy, and irony (the phrase "assimilated self haters" suggests itself). In effect the forcible re-catholicisation of Vienna and much of eastern Austria produced a quasi-secularization of society as people were forced to pay lip service to a set of values in which they had ceased to believe. Think of the situation of former inner-directed Protestants, who now must observe Catholic ritual despite their consciences. The only possible result would have to be cynicism with respect to both religion and politics, as well as an inner emptiness that often prompts them to seek theatrical surrogates for the missing selffulfillment. If this is true, we should find Viennese hedonism and escapism linked to a peculiar set of 'alienated' religious values - and, indeed, we do. Boyer, for example, calls attention to the fact that underneath the surface glitter of Viennese Catholicism there lurks another religion, that of the Biedermeier "Herrgott" that at best employs certain Catholic symbols and expressions, but is really a kind of sentimentalized, fatalistic theism: ${ }^{52}$ "Wenn der Hergott nicht will, nützt es gar nix" (which might be loosely translated, "if the Good Lord ain't willin', fergit it") runs a well-known Wienerlied that captures perfectly the popular Viennese concept of Providence. ${ }^{53}$ Thus the Viennese disposition, which extends into the political sphere, to melancholy and the tendency to escape into an operetta-like fantasy world are part of a long story that takes us back to Luther's time.

This thesis, like Kann's, has not yet been put to the test but it certainly should be. That would be to raise the kind of questions about the ways in which Baroque values have been transmitted from the seventeenth century that are typical of French, anthropologically-oriented history, which have yet to be applied in the Austrian context. The work of R.J.W. Evans on the transition from Renaissance to Baroque (although not in the French tradition), marks a serious move in this direction. ${ }^{54}$ Considerations of space allow me to do little more than hint at its importance. Evans has tried to specify how the Austrian variant of the Baroque only half succeeded in producing absolute monarchy but ended up "a complex and subtly-balanced organism, not a 'state' but a mildy centripetal agglutination of bewilderingly heterogeneous elements" 55 linked by a common mentality, that was too traditional to accept modernization, but too modern to be content with tradition. The result was that by the turn of the century Austria held fast to all sorts of colorful traditions officially, while ignoring them in practice or worse

52 Boyer, op. cit., 117 (see n. 20).

53 Thus Hitler's fanatical fatalism, which was the other side of the coin of his fanatical belief in his own will, can be taken to be continuous with Viennese sentimental fatalism even if it is not identical with it. On Hitler's fatalism see J.P. Stern, Hitler: The Fuhrer and the People (Berkeley, University of California Press, 1975), 61, 222, et passim; cf. Sebastian Haffner, Anmerkungen zu Hitler (Munich, Fischer, 1983), 153 et passim.

54 R.J. W. Evans, The Making of the Habsburg Monarchy 1550-1700 (Oxford, Clarendon Press, 1979)

55 Ibid., 447. 
exploiting them for commercial purposes, as has been the practice in Salzburg. ${ }^{56}$ It is crucial to fill in the outline he has sketched from the end of the Counter Reformation to the fin de siècle, for example, to see how magic and superstition has been transmitted from the Baroque to the fin de siecle (and farther). More importantly the half-completed centralization process would seem to account for the curious sort of "melting pot" that Vienna 1900 would become. Evans' work suggests at once certain comparisons with centralized capitals such as Paris or Stockholm and with American cities such as New York or Chicago. Finally, it goes a long way to explaining the half-heartedness of the Viennese use of language, i.e., more as ornament to social life than as a vehicle for conveying literal singnifcance.

In any case, if Boyer has emphasized the distance between the public and the private in nineteenth century Viennese politics, Barea and Evans have offered us an explanation of how that gap came into existence. In doing so both of them have given us the explanation of what is perhaps the major difference between a typically Austrian and a typically German mentality, for, as Ralf Dahrendorf has emphasized, Germans are only able to cope with conflict so long as they believe that a solution at some "higher level" is possible. ${ }^{57}$ However, this is exactly the opposite of the Austrian, especially east Austrian, as opposed to the Alpine, and, above all, the Viennese mentality, which has no problems with conflicts but skeptically and even cynically, considers all solutions to pressing conflicts absurdly utopian; while accepting, and almost masochistically glorying in, the resultant ambiguity. Thus, whereas in Berlin a situation could be serious but not desperate; in Vienna it could be desperate but not serious, as Kraus put it.

And this brings us - finally - to our second paradigm. Where the devil is abroad, the Holy Ghost cannot be far away, to paraphrase Ferdinand Ebner.

It is precisely because the "value vacuum" of which Broch speaks, that obsession with novelty which arises as one set of values becomes passé without yet being replaced by another, evoked a far deeper response than the "mysticism of nerves" that gave us the avantgardism of "Young Vienna", "Jugendstil" and the Secession, as well as Lueger and Co., that the "failure of liberalism" thesis has been challenged by what I have termed the "critical modernism" thesis. I have coined the term "critical modernism" in explicit contrast to superficial postmodernism, which has sometimes wanted to claim fin de siècle Viennese "decadence" as an anticipation of certain crucial aspects of "post-modernity". The "critical modernist" paradigm, on the contrary, turns on the hypothesis that the most important contribution of fin de sieccle Vienna to our culture is a peculiarly skeptical healthy reaction against the spellbinding power which modernity exerts upon us. Its Viennese representatives, who were by no means its only representatives and never particularly popular in Austria down to our own day, are distin-

56 On "Modernisierung via Fremdenverkehr" see Ernst Hanisch and Ulrike Fleischer, Im Schatten berühmter Zeiten: Salzburg in den Jahren Georg Trakls (1887-1914) ("Trakl Studien" Vol. 13; Salzburg, Otto Müller, 1986) 51-4. The little discussed notion of modernizing through tourism is of the utmost importance for understanding the Alpine regions of Austria from the turn of the century and the rest of Austria including Vienna, which became "provincialized" in this respect as capital of rump Austria. Modernization via tourism helps to explain Austrian reluctance to come to grips with the shadier aspects of the Austrian past such as anti-Semitism etc. in the great international exhibitions, which are principally conceived as tourist attractions.

57 Ralf Dahrendorf, Society and Democracy in Germany (New York, Doubleday, 1967) 129-155. 
guished by the power of a critique of modernity that, nevertheless, was not a rejection of modernity pure and simple, but an immanent critique of its limits.

"Critical modernism", 58 then, is a label that I have invented after the fact to describe a cast of mind, not a conscious movement nor even all of the works of the figures that I use to designate it; rather critical modernism is the property of their foremost achievements. It has two aspects: critical modernism refers, first, to a scathing diagnosis of that attitude to culture, which considers art's power to move us emotionally by being bigger than life as a drug to get "high" on, secondly, it is a strategy for combating the Narcissistic, theatrical, solipsism that was part and parcel of both the Viennese religion of art and its "politics of fantasy" that was the correlative of that Narcissism. The figures that this term designates ${ }^{59}$ were for the most part inspired by the critique of fin de siècle Viennese mores inspired by Karl Kraus, Adolf Loos and the much-misunderstood, Otto Weininger, whose work we have only recently begun to comprehend thanks to the researches of Hannelore Rodlauer, Waltraud Hirsch and Steven Beller. ${ }^{60}$ They include, for example, Arnold Schoenberg ${ }^{61}$, Egon Schiele in the last years of

58 Here we must distinguish at the philosophical level between modernism understood as the view that there are true for all time criteria of rationality that can be comprehensively represented in a single theory (the "verificationism" of the Vienna Circle, Lenin's "dialectical materialism", and Habermas' "theory of communicative action" would be three examples), anti-modernism (the wholesale rejection of everything that has to do with industrialized society in favor of some romantic ideal of lost communitarian values), post-modernism ("anything goes": the simple negation of the modernist monolithic account of rationality), and "critical modernism" the pluralistic, because practice-immanent search for the criteria which make it possible to carry on particual activities based upon the analysis of specific cases, i.e., which does not prejudge the normative issues by imposing universally valid scheme or give up in despair at ever arriving at any criteria for evaluating anything. Popper's "falsificationism" is a step in the direction of "critical modernism" which finds it full expression in Wittgenstein's differentiating efforts to base reflection upon the nuances of particular cases. Martin Seel has made an eloquent plea for a "second modernism", free of the abuses of the first, corresponding to what I understand under "critical modernism" in his "Plädoyer für eine zweite Moderne", Die Aktualität der "Dialektik der Aufklärung" zwischen Moderne und Postmoderne ed. Harry Kunnemann et al. (Frankfurt, Campus, 1989), 36-60.

59 It should be pointed out that critical modernism is first and foremost an attitude to culture. None of the figures in question incorporated this attitude in all of their work - let alone their personal lives as Lisa Fischer's study of Lina Loos (n. 5) clearly indicates with respect to Adolf Loos. Many of the designs of Adolf Loos, for example, are clearly products of classical modernist megalomania, i.e., his sketches for his Chicago skyscraper or his plans for the re-structuring of Vienna. The point is that his most important achievements are precisely those that call the assumptions of classical modernism into question. I have profited from conversations with Hans Veigl concerning the ambiguities of Viennese "modernism".

60 See Dr. Rodlauer's introduction to Otto Weininger, Eros und Psyche: Studien und Briefe, ed. H. Rodlauer (Vienna, Verlag der österreichischen Akademie der Wissenschaften, 1990), 11-51, Waltraud Hirsch, Eine unbescheidene Charakterologie: geistige Differenz vom Judentum und Christentum als Lehre vom bestimmten Charakter bei Otto Weininger (unpublished dissertation; Tübingen, 1995), Steven Beller, op. cit., 221-36 (see n. 6), and my "Weininger's Vienna: the SexRidden Society" in Steven E. Bronner's forthcoming anthology, Vienna: the World of Yesterday 1889-1914 (New York, Humanities Press, in press).

61 On Schoenberg's critical modernism see my "Schoenberg's Vienna: the Critical Modernism of a Viennese Composer", Nexus 12 (1995), 43-68 [in Dutch]. 
his lamentably short life ${ }^{62}$, Ludwig Wittgenstein ${ }^{63}$, Georg Trakl (a figure who has hardly even been mentioned in connection with fin de siècle Vienna), ${ }^{64}$ Hermann Broch, ${ }^{65}$ and later the T.W. Adorno of the "Meditations on Metaphysics" ${ }^{166}$, Erwin Chargaff ${ }^{67}$ and Felix Mitterer ${ }^{68}$ to mention but a few. However, I would also insist upon including any number of figures outside the sphere of Kraus's influence and even some of his antagonists such as Freud, Schnitzler, in some of his moods eg. The Far Country, ${ }^{69}$ Robert Musil, ${ }^{70}$ and Rosa Mayreder among the critical modernists. Mayreder's feminism with its skeptical attitude to many feminist clichés such as the universal enemy 'man' or the 'sacrificing' woman, ${ }^{71}$ for example, is exactly the sort of thing I want to call attention to under the rubric "critical modernism".

Inasmuch as they concentrated upon art, critical modernists were all concerned in one way or another with extricating Viennese aesthetes from their cultural day dreaming, i.e., what the Brenner philosopher Ferdinand Ebner called Traum vom Geist or "intellectual fantasizing". ${ }^{72}$ The critical modernists press crucial questions about the aims and goals of artistic activity based upon profound medium-immanent reflections in their creative work itself as Kraus does

62 Leon Botstein, "Egon Schiele and Arnold Schoenberg: the Cultural Politics of Aesthetic Innovation in Vienna 1890-1918", Egon Schiele: Art, Sexuality,and Viennese Modernism, ed P. Werkner (Palo Alto, Society for the Promotion of Science and Scholarship, 1994), 101-118.

63 See Janik and Toulmin, op. cit. (n. 25) and my essays, "Nyíri on the Conservatism of Wittgenstein's Later Philosophy" and "Wittgenstein, Marx and Sociology" in my Style, Politics and the Future of Philosophy (see n. 4).

64 On Trakl see my "Georg Trakl und die Zerstörung des habsburgischen Mythos", Studia Trakliana, ed. F. Cercignani (Milan, Cisalpino-Goliard, 1989), 51-62; cf. Walter Methlagl, "Der schlafende Sohn des Pan", Studia Trakliana, 63-80, and his "Nietzsche und Trakl", Frühling der Seele, ed. G. Stieg and R. Colombat ("Brenner Studies" Vol. 13; Innsbruck, Haymon, 1995), 83-123. One of the few scholars to follow my usage is C.P. Berger in his unpublished study Georg Trakls Begegnung mit Ludwig Wittgenstein: eine Kulturtheorie der österreichischen Moderne.

65 Broch practically defined the aesthetic position that I refer to as critical modernism in an early essay, "Notizen zu einer systematischen Ästhetik", which was rejected for publication in the Brenner by Ludwig von Ficker in 1913 (typescript, Brenner Archives); cf W. Methlagl "Der Brenner' - Beispiel eines Durchbruchs zur Moderne!, Mitteilungen aus dem Brenner Archiv, 2 (1983), 11-2.

66 T.W. Adorno, "Meditationen zur Metaphysik", Negative Dialektik (Frankfurt, Suhrkamp, 1990), $354-400$.

67 On Chargaff see W. Methlagl, "Von Wright, Chargaff och Heraclitus's_Fire", Dialoger [Stockholm], 26 (1992), 32-8.

68 W. Methlagl has drawn my attention to the fact that Mitter's Stigma, for example, stands in a critical modernist relation to Baroque drama.

69 Arthur Schnitzler, Das weite Land, Das dramatische Werk (2 Vols., Frankfurt, Fischer, 1962), II, 217-320.

70 Musil's extended meditation on both "Genauigkeit" and "Seele", i.e. on both natural science and what he called "the other condition", intense feeling or the state of being enraptured is a case in point; cf. Musil "The German Personality as Symptom", Austrian Philosophy, ed. J.C. Nyíri (Munich, Philosophia, 1981), 173-200.

71 Harriet Anderson, op. cit., 52 (see n. 5).

72 Ebner's campaign against Traum vom Geist or intellectual fantasizing is a paradigm case for defining critical modernism. On Ebner see my "Offenbach - konsten mellan monolog och dialog", Cordelias tysnad (Stockholm: Carsson's, 1991), 45-63 and "Ebner contra Wagner: Erkenntnistheorie, Ästhetik und Eriösung in Wien um 1900", Kreatives Milieu Wien um 1900, eds. E. Brix and A. Janik (Vienna, Verlag für Politik und Geschichte, 1993), 224-41. 
by making texts out of the texts of others. Thus, explicitly or not, they rejected with Nietzsche the monumentality of the Wagnerian Gesamtkunstwerk for a minimalist Gesamtkunstwerk that found the message in the medium itself. Thereby they could build a pregnant Wittgensteinian "silence" into the very structure of, say, their music in the case of a Schoenberg or a Webern or their poetry as in the case of Trakl.

Indeed, it was Trakl who produced the most devastating critique of Viennese aestheticism of all, because his critique of aestheticism was entirely immanent. Long confused with 'primitives' and expressionists, careful study has shown that Trakl was an absolute perfectionist whose art was directed against the "value vacuum" in a "cursed, godless century". ${ }^{73}$ Master of all the avantgarde techniques for writing poetry that Symbolist poets had inherited from Rimbaud and Baudelaire, Trakl turned those techniques against the avantgarde art as he did the symbols of Baroque Catholicism or German Romanticism to show, in Wittgenstein's sense, the emptiness of an art that poisoned itself in its own beauty. In the very structure his poems, Trakl contrasted the Symbolists' Narcissisitic obsessions with the personalism of Dostoievskian Christianity in its sensitivity to the lot of the helpless and the downtrodden. It is a mark of his success that this poetic critique of the spiritual barrenness of his age remained powerful enough to inspire the likes of Ingeborg Bachmann, Paul Celan, Christine Lavant, Thomas Bernhard and many others decades after his death. Trakl is particularly important as a contrast figure to the Schorske thesis because his poetry contains probably the most scathing critique of Nietzsche ever written. ${ }^{74}$

Kraus set the tone for this group by providing a critique at once of the "politics of fantasy" and the "Romanticism of nerves", not to mention the hypocrisy of an authoritarian Church, precisely by refusing to tolerate a situation in which words did not mean what they said. His campaign against Austrian slovenliness (Schlamperei) took the two-fold form of an assault upon the Austrian public's tolerance for ambiguity and artistic cultivation of it. Although he would increasingly after World War I assume the role of an Old Testament prophet in ways that became increasingly problematic, Kraus, as Harry Zohn and Reinhold Merkel emphasize $^{75}$, began his career as a sort of casuist critic of the misuse of language in public life. His first polemics were directed in good liberal fashion at the collusion of public officials, priests, and journalists who allowed the moral and the criminal, the private and the public aspects of conduct to become fatally confused, but worse than that exploited that very confusion for profit. In a society in which such confusions were possible rational intercourse between citizens was impossible. In fact Kraus was among other things protesting that the kind of gap that existed in Vienna between what people said and what they meant made "civil society" (what Habermas calls "Öffentlichkeit"176) impossible. The assumption behind his early polemics is that without integrity there can be no public life. Without the integrity of language there could

73 Georg Trakl, Letter to Ludwig von Ficker, 26.VI.13. Historisch-kritisch Ausgabe, eds. W. Killy and H. Szklenar (2 Vols.; Salzburg, Otto Müller, 1969), II, 519.

74 See Methlagl, "Nietzsche und Trakl" (n. 64).

75 Harry Zohn, Karl Kraus (New York, Twayne, 1972), 42; Reinhard Merkel, Strafrecht und Satire im Werk von Karl Kraus (Baden-Baden, Nomos, 1994), passim.

76 See Jürgen Habermas, Strukturwandel der Öffentlichkeit (Neuwied, Luchterhand, 1962), passim. 
be no personal integrity. If we start by debasing language we end up debasing people. From his early campaigns for the rights of prostitutes and homosexuals, to his attacks on Lueger and later Bekessy and Schober, and, above all, his commentary upon the sort "double think" that lay behind the rhetoric of the Central Powers' leadership in World War I in his monumental play The Last Days of Mankind Kraus was doing nothing more than objecting violently to Viennese and Austrian tolerance towards the very sort of ambiguity in public life that made Lueger possible. This is not to say that Kraus was always right in his judgments but that the target of his polemics, lack of integrity in the use of language, was precisely what was separating Austria increasingly from the mainstream of western liberalism. If liberalism failed in Vienna, it was not the fault of Karl Kraus ${ }^{77}$.

Be that as it may, the most exciting development in Austrian studies recently has been the recognition of the "Jewish" character of "critical modernism" It is the merit of Steven Beller to have done so (before the concept existed as such). This is particularly impressive because once upon a time it seemed that it would be impossible to prove that the achievements of the Viennese Jews, of which everybody had always been conscious, were due to their Jewishness rather than their liberalism. On the basis of an astute statistical analysis Beller shows us how Jewish over-representation within the educated class (i.e., Gymnasium graduates) put Jews in a position to dominate Vienna's intellectual life from 1867 to $1938^{78}$, in much the same way that Jews have come to dominate, say, that of New York for most of this century - i.e., by "setting a tone" to intellectual life so as, say, to draw a young Catholic philosopher like me to finish his education at a Jewish university. Beller emphasizes that before and after these dates Vienna has been a relatively uninteresting place. Moreover, on the basis of an even more astute analysis of the moral values of so-called "assimilated" Jewry, he demonstrates why it was imperative for them actively to "Judaize" Austrian society ${ }^{79}$, and exactly what it meant to do so. In stark contrast to Catholicism, whose hierarchical structure has made acceptance of Enlightenment highly problematic, if not outright impossible to this day, the Jewish Enlightenment (haskalah) was able to produce a secular synthesis of traditional Judaism and Kantian moral philosophy, which turns upon the absolute duty of rational beings to act rationally. Thus classical German culture took on virtual religious significance as the German classics, first in connection with natural science, later literary and aesthetic culture generally, replaced the Talmud. Thus from 1848 onwards as "assimilating" Jews gravitated in increasing number towards the Habsburg capital they came with the idealistic (both in the philosophical and the colloquial sense) project of becoming Germans. When they arrived in Vienna they discovered to their dismay that before they could do that they had to liberate Austrians from the fetters of ignorance bound up with superstitious Baroque Catholic values, to replace an ornamental pictorial culture with a critical culture of the Word. ${ }^{80}$ Thus "assimilation" was anything but a passive process of adaptation to their new environment, rather it was a project, not a bit like

77 See Merkel, op. cit., 154-5 (n. 75).

78 Beller, op. cit., 33-70 (see n. 6).

79 Ibid., 153.

80 For a trenchant comparative analysis of the impact of the Enlightenment upon Judaism and Catholicism see David Sorkin, "From Context to Comparison: the German Haskalah and Reform Catholicism", Tel Aviver Jahrbuch für deutsche Geschichte, 22 (1991), 23-58. 
Habermas's project to become modern, ${ }^{81}$ to introduce the culture of Kant, Beethoven, Goethe and, above all, Schiller to a deprived people raised on Abraham a Santa Clara. However, it is important to emphasize that this critical spirit viewed 'unenlightened', orthodox Jewry every bit as deprived and thus criticized its shortcomings roundly. This Jewish self-critique is often confused with another very different, very real, phenomenon, self-hatred. ${ }^{82}$ Nevertheless, it was paradoxically a strongly Protestant value system that assimilating Jews both imparted to Vienna's liberal intelligentsia (and supported financially) both by their example and in their salons. So it should not be particularly surprising that the crypto-Protestant ${ }^{83}$ "critical Catholicism" 84 (sadly neglected by cultural historians) that emerged in and around Ludwig von Ficker's Der Brenner in Innsbruck after World War I, which bitterly and unqualifiedly condemned the Salzburg Festival as idolatrous, should have at once developed out of, and in reaction to, Karl Kraus in exactly the same way that, say, the thought of Elias Canetti did ${ }^{85}$. Both grew out of a secularized Jewish passion for truth in their very different ways.

I suspect that the achievement involved in laying bare the Jewish foundations of Enlighenment in Vienna 1900 would have pleased Robert Kann very much. When one reads his account of Josef von Sonnenfels in his Study in Austrian Intellectual History closely and carefully after Beller, and in connection with, say, the penetrating studies of Bruce Pauley on the anti-Semitism of the inter-war years ${ }^{86}$, one senses movingly the agony that the Jewish 'enlighteners' of Austrian society were to experience "between the lines" as it were in Kann's exposé. Kann's translator told me that the book that became Kanzel und Katheder in German was far and away the most difficult she had ever undertaken and seriously entertained my suggestion that her practical difficulties were connected with the fact that Kann could not really bring himself to express all of the hard truths about the Viennese rejection of assimilated Jews and

81 With the difference that Habermas is not "idealistic" in the colloquial sense in the way that Viennese liberal Jews were. In a sense the ideal was more real than the world before them, the difference between them is the latter's belief in the ideology of "progress" which was extinguished by World War I.

82 On the problems surrounding the notion of "self-hatred" see my "Viennese Culture and the Jewish Self-hatred Hypothesis: a Critique", Jews, Anti-Semitism and Culture in Vienna, eds. I. Oxaal, M. Pollack, and G. Botz (London, Routledge \& Kegan Paul, 1987), 75-88.

83 See Gerald Stieg, "Ferdinand Ebners Kulturkritik: Am Beispiel der Salzburger Festspiele", Gegen den Traum vom Geist, eds. C. König et al. ("Brenner Studien" Vol. V; Salzburg, Otto Müller, 1985), 243.

84 C.P. Berger, "Kritischer Katholizismus versus kritische Theorie: der Brennerkreis und die ältere Frankfurt Schule", Mitteilungen aus dem Brenner Archiv, 10 (1991), 72-92.

85 I am grateful to Gerald Stieg for information about Canetti; cf. his Ebner essay (see n. 83), 241. On Kraus and the Brenner see Stieg's seminal study Der Brenner und die Fackel ("Brenner Studien" Vol. 3; Salzburg, Otto Müller, 1977). For on overview of the history of the Brenner, the only periodical to survive both world wars, see Walter Methlagl and Allan Janik, "Der Brenner", Major Figures of Austrian Literature: the Interwar Years 1918-1936, ed. Donald G. Daviau (Riverside, Ariadne, 1995), 83-106.

86 See his "Political Anti-Semitism in Interwar Vienna", Jews, Antisemitism and Culture (n. 82), 152 73 and From Prejudice to Persecution: A History of Austrian Anti-Semitism (Chapel Hill, London, University of North Carolina Press, 1992). 
Enlightenment that he wanted enunciate. ${ }^{87}$ I have certainly been shaken reading Kann again after Beller.

Be that as it may, we have our second paradigm. But do we have one or two paradigms here? We certainly have two very different, opposed theses about Vienna 1900. Both the "failure of liberalism" and "critical modernism" fill the three criteria for being a paradigm: they allow us to see things together that we could only previously see separately both are exemplars which are being imitated in current research, both have provoked an exciting and illuminating discussion, but are they "incommensurable and incompatible" as different paradigms must be according to Kuhn? The answer would seem to be: yes and no. They are certainly incompatible with respect certain specific points, say, to classifying Viennese upper middle class culture as a culture of "grace", which developed in imitation of aristocratic sensuousness. In fact Beller has argued that there was precious little that would count a high culture in aristocratic circles for liberals to imitate. The central role of military virtue, so central to callous villany in the works of Schnitzler, and its leisure time equivalent, hunting in aristocratic life, were as foreign to the Viennese liberal intelligentsia as they were to orthodox Jews. To the extent that there was culture at all - even when it was verbal - it was musical and pictorial, amusing not challenging, in a word not literary as was liberal culture. ${ }^{88}$ So there are clearly points of deep disagreement. On the other hand, there is also a high degree of complimentarity between the two theses as the argument of Wittgenstein's Vienna itself would attest. On this view "critical modernism" came into existence as a response to the "failure of liberalism". So there is room for doubt about whether we really have a clash of paradigms here. Time will tell.

Perhaps we ought to be developing a synthesis in the form of a "failure of Jewish liberalism" thesis. The depth of Jewish commitment to liberalism, by the way, can be measured by the fact that the right to vote in the Israelitische Kultusgemeinde remained attatched to the payment of 10 florins tax till the end of the monarchy 89 . Consider briefly the following caricature of a sketch: if we read "Jewish liberalism" where Schorske has simply spoken of liberalism, if we further consider with Boyer that Viennese liberals were illiberal in fundamental respects, and we go on to substitute the traditional Viennese values, nostalgically evoked in the phrase, "Backhendl Zeit", for the "aristocratic culture of grace", as Boyer and Barea suggest we should, we get a picture of a younger generation of Jewish liberals deserting the One True God, i.e. Kant and Schiller's Rational Ideal, not for Catholicism itself, but for its debased, counterfeit, sentimental "Herrgott" Mammonism, now in various secularized aestheticized guises. That desertion then provokes a reaction on the part of equally dissatisfied contemporaries who insist that it is not "Jewish liberal values" that are at fault but the fact that the older generation failed often to live up to them. The resulting picture is one combining the corrected "failure of liberalism" thesis with the "critical modernism" thesis in a long term

87 Personal communication from Dr. Inge Lehne.

88 In this connection it is worth quoting Hilde Spiel quoting Madame de Staël: "Few books were read in the great houses to which she was invited and no writers were received. 'It results from that separation of classes that the literary people lack grace and the fashionable people rarely receive instruction'". Vienna's Golden Autumn (London, Weidenfeld \& Nicholson, 1987), 38. There is little reason to think that this changed much.

89 Robert Wistrich, The Jews of Vienna in the Age of Franz Josef ("The Littman Library of Jewish Civilization"; Oxford, Oxford University Press, 1989), 90-1. 
story, which looses none of it poignancy for being in a very deep sense an internal 'Jewish' debate. The result of such a thought experiment leaves us remarkably, even disquietingly, close to the argument of Chapters 13 and 14 of part II in Weininger's Sex and Character.

Perhaps the future lies in that direction, which, of course, is not without its thorny problems. Such an approach would have to "square the circle" by doing justice both to Kraus and Lueger, to morality and politics. That in turn would involve little more than analysing the deepest problems in our own culture ${ }^{90}$ - but then is not all history contemporary history as Benedetto Croce suggested? and is it not precisely this aspect of Schorske's work that has made Vienna so important in the first place? Be that as it may, since squaring the circle is a good seventeenth century Austrian preoccupation as Evans points out ${ }^{91}$, we should not shy away from it.

\section{Problems for Future Research}

I would like to conclude by enumerating a list of problems for future research (not all of which arising from the perspective of critical modernism), which I take to be particularly pressing. Most of them turn in one way or another upon the importance of social history for understanding the link between politics and culture. In doing so I in no way want to imply that my list is exclusive, it only claims to emphasize areas that are particularly neglected. Thus I have not mentioned the whole area of women's studies because considerable work is being done in the area even if its implications for our paradigms of Vienna 1900 have not become clear.

Analytic philosophy has taught us that we are only in a position to understand the meaning of a word, sentence, sign or symbol to the extent that we know how it was used normally at the time it was uttered or written. Moreover, usage changes over time. Thus the history of the reasons for an causes of such changes in rhetoric will be crucial to the project of cultural history.

1. Social history is also the key to the dynamics of the transmission of values. We need to understand, for example, the genesis and development of the "Herrgott" religion, but we also need to know in detail how the north German ideal of haskalah spread to and in Vienna. To that end we need to cultivate the sort of social history that has been so highly developed in France, i.e., history with a long-term perspective concentrating upon "those who have suffered, worked, declined and died without being able to describe their sufferings". Moreover, the sort of history of "moeurs" that Emanuel LeRoy Ladurie has brought to perfection in works like Montaillou and Carnival is wholly lacking in the area of Austrian studies. As a result we have had more or less to take Baroque Catholicism at its own word with respect to the significance any number of beliefs and practices.

90 This claim should be compared with the provocative thesis of Isaiah Berlin in his "Political Ideas in the Twentieth Century", Four Essays on Liberty (Oxford, Oxford Univesity Press, 1969), 1-40, arguably the most trenchant study in twentieth century western political ideas yet to appear.

On this "problema Austriacum" see Evans, op. cit., 335 (see n. 54). 
Another value constellation that has all but gone unresearched is the Neo-Stoic ethos of the civil service as it develops out of the political philosophy of Lipsius into the Enlightenment through the nineteenth century and down to Kafka. ${ }^{92}$

To understand the significance of many social phenomena in literature we need to know what social reality was. For example, to understand the role of the ubiquitous prostitute in literature we must know what the prostitution was like in practice in Old Vienna, a theme that has only of late been investigated for the first time, significantly, by a scholar working in Holland. ${ }^{93}$ Similarly, we shall certainly not be in a position to understand the world of Schnitzler's Anatol until we have an accurate picture of what it was to be independently wealthy around 1900 . The question of just who got rich and just how rich they got in the "Gründerzeit" remains to be posed, not in the context of industry but in the context of understanding how both Jugendstil art and a decadent life-style was financed.

2. Equally important and equally dependent upon the creation of a social history of Austria would be an Austrian equivalent of the project in civil courage that issued in Ralf Dahrendorf's redoubtable "Society and Democracy in Germany". Austrian history and social science will not come of age till an Austrian is brave enough to raise the question why it took two world wars to achieve a semblance of western "civil society" and learned enough to answer it plausibly. That person will have to explore notions of equality as they relate to the process of industrialization and economic modernization, the traditional elites and education, the development of law and the legal profession, attitudes to authority, modes of distinguishing between public and private, etc, etc. That person will, like Dahrendorf, probably have to be a member of the House of Lords and Vice-Chancellor of an English university as well as being an Austrian.

3. Since most of the "big" questions that we want to raise about Viennese and Austrian culture in one way or another turn upon that question of just how 'rational' developments there have been one important desideratum concerns the history of natural science, which is perhaps our most important measure of 'rational' activity. In this area there has been practically no research whatsoever. The sheer number of first-rate scientists that came from fin de siècle Vienna is astounding. It was only there that four future Nobel prizes winners attended the same Gymnasium at the same time. Erna Lesky has given us a comprehensive picture of the state of medical research in Vienna 1900 but really has only scratched the surface, so rich was Vienna's medical science at the turn of the century. ${ }^{94}$ All of this needs to be integrated into our discussions of culture. If we want to learn about the mental habits of Viennese intellectuals

92 Gerhard Östreich has laid the foundations of such a study in the essays collected in the volumes Geist und Gestalt des frühmodernen Staats (Berlin, Duncker \& Humblot, 1969) and Strukturprobleme der Neuzeit, ed. B. Östreich (Berlin: Duncker \& Humblot, 1980. I have benefitted from conversations with Raoul Kneucker and Waltraud Heindl on this subject.

93 See Karin Jusek, Auf der Suche nach dem Verlorenen. Die Prostitutionsdebatte im Wien der Jahrhundertwende (Wien, Löcker, 1994).

94 Erna Lesky, The Vienna Medical School of the Nineteenth Century, trans. J. Levij (Baltimore, John Hopkins University Press, 1976. 
before World War I, for whom natural science was a vitally important part of culture, we shall need to know more about the history of science.

Further, since the nature, importance and social role of science is central to debates about Enlightenment, it is crucial when we are evaluating figures of the fin de siècle to establish how the opinions of philosophers, social critics and literati along a broad spectrum from racists to feminists stood in relation to "best knowledge" in the natural sciences. For example, the number of "Monists" among Viennese intellectuals was simply huge. To evaluate their opinions, i.e., to distinguish science from speculation in their thought we need to know how the understood, say, Darwin and how that understanding relates to developments in zoology at a specified time.

In more remote periods such as the seventeenth century the Habsburg monarchy produced relatively few first-rate scientists but what passed for science is highly revealing of the intellectual values of the society. I refer to the preoccupation with the "squaring of the circle". Now that reputable historians of science have taught us that it is not only legitimate but absolutely necessary to the enterprise of the history of science to concern ourselves with 'false', which they assure us are usually less 'false' than we think, ideas we ought to start taking a serious look at the development of the natural science and medicine in Vienna.

4. Another very different sort of studies that we ought to be concerning ourselves with comparisons with the other great urban centers in Europe and America. To understand the role of Vienna in the monarchy with respect to, say, Prague or Czernowitz we should be looking into, say, the relationship between London and Edinburgh or Dublin or Manchester. To some extent the sort of comparative perspective has begun to be employed as scholars from Prague, Budapest and Zagreb explore their historical relations with the Habsburg capital. But we need yet other types of social comparative studies too. Since there is absolutely no question that Vienna, like New York, Chicago or London was a magnet for immigrants we ought to be seeking to determine what was unique about Vienna by comparing it with other "melting pots". The point of these comparisons is as much to get clear about just what a "melting pot" is as it is to get clear about, say, the role of immigration in Viennese politics. While the comparisons of Vienna with other centers with the monarchy are interesting and important this theme is crucial if we are to understand the politics of "the little man" that, we should remember, was displacing liberalism in the great American industrial cities increasingly after the Civil War.

5. Finally, the question that Robert Kann posed about explanations of Viennese culture in terms of alternating cycles of rational and irrational dominance within public life remains. If Kann's approach seems too speculative and abstract I would remind skeptics that the best account we have of irrationalism in the United States, that of Kann's brilliant contemporary Richard Hofstadter takes exactly that form by tracing the roots of American anti-intellectualism back to the "Great Awakening" in $1740 . .^{95}$ As for the question of his use of ideal types: do

95 Richard Hofstadter, Anti-Intellectualism in American Life (New York, Vintage, 1967). Like Dahrendorf's study of society and democracy in Germany Hofstadter's well-documented book claims to be an exercise in civil courage more than an academic study. If they are accurate in 
we not in fact recognize them when we take a close look at today's Austria? Does not the demagogic voice of Abraham a Santa Clara albeit in an institutionalized form and sans stylistic brilliance resonate through the pages of the Kronenzeitung? Have not today's 'enlighteners' such as Simon Wiesenthal shared Sonnenfels fate of ultimate rejection despite limited superficial success. There are indeed reasons for taking Kann seriously today. These issues and many more need to be reconsidered.

describing their work, the importance of both of these books ought to tell us something about standard "academic" priorities. One very important reminder to American students of Austrian culture implicit in Hofstadter's work is the closeness of American and Austrian froms of political fundamentalism. Prof. Schorske himself has pointed out how the Chinese Exclusion Act of 1882 was a model to Schönerer, 129 (see n. 18); whereas Pauley has indicated that the quotas on Jewish students that Viennese anti-Semites demanded in the 30s were already in effect at American elite institutions like Harvard, 94, 128. (Pauley 1992, see n. 86) 